\title{
Isothermal Kinetics of Catalyzed Air Oxidation of Diesel Soot
}

\author{
R. Prasad*, and Venkateswara Rao Bella \\ Department of Chemical Engineering \& Technology, Institute of Technology \\ Banaras Hindu University, Varanasi 221005, India
}

Received: 14th June 2010; Revised: 18th July 2010; Accepted: 9th August 2010

\begin{abstract}
To comply with the stringent emission regulations on soot, diesel vehicles manufacturers more and more commonly use diesel particulate filters (DPF). These systems need to be regenerated periodically by burning soot that has been accumulated during the loading of the DPF. Design of the DPF requires rate of soot oxidation. This paper describes the kinetics of catalytic oxidation of diesel soot with air under isothermal conditions. Kinetics data were collected in a specially designed mini-semi-batch reactor. Under the high air flow rate assuming pseudo first order reaction the activation energy of soot oxidation was found to be, Ea $=$ $160 \mathrm{~kJ} /$ mol. C 2010 BCREC UNDIP. All rights reserved.
\end{abstract}

Keywords: Soot emissions; Soot oxidation; Isothermal kinetics

\section{Introduction}

The diesel engines find widespread applications as power source in both automotive and stationary applications. They are energy efficient, durable, driveable, etc. [1] but their emissions of particulate matter (PM) and NOx are responsible of severe environmental and health problems [2]. Specifically, diesel PM has led the legislation to adopt stringent emission standards. Diesel particulate filters (DPF) are becoming wide spread as an effective measure to reduce PM (soot) emissions from diesel vehicles as they have filtration efficiencies of almost 100\% [3]. As the filters accumulate PM, it builds up backpressure that has many negative effects such as decreased fuel economy and possible engine and/or filter failure [4]. To prevent these negative effects, the DPF have to be regenerated periodically, i.e. the combustion of the accumulated particulates.
It is therefore, vital to understand the regeneration process in order to optimize the application and operation of DPF both for lifetime durability and fuel economy purposes. However, diesel soot elimination is known to be a hard task, since this material burns at roughly $550-600{ }^{\circ} \mathrm{C}$ with air, while diesel exhaust gases temperature most of the time lies between $200-450{ }^{\circ} \mathrm{C}$. Therefore, some artifice is needed to promote soot oxidation. Very often this is carried out by the use of an oxidation catalyst based DPF [5] in order to lower the required combustion temperatures.

The catalysts are impregnated on the filter walls. The performance of catalytic traps is affected by the intrinsic catalytic activity and the soot-catalyst contact efficiency [6]. The nature of the contact between soot and the catalyst depends on two important parameters: the relative concentration of the solids and the mixing method.

* Corresponding Author.

E-mail address: rprasad.che@itbhu.ac.in (R. Prasad)

Tel.: +91542 2367323, fax: +91542 2368092 
Table 1. The reported activation energy (E) of the various soot-catalyst mixtures

\begin{tabular}{|c|c|c|c|c|c|}
\hline Ref & $\begin{array}{l}\text { Cat \& Prepn } \\
\text { method }\end{array}$ & Experimental & Operating parameter & $\begin{array}{l}\text { Iso-/Non- } \\
\text { Isothermal }\end{array}$ & $\begin{array}{l}\mathrm{E} \\
(\mathrm{kJ} / \mathrm{mol})\end{array}$ \\
\hline 10. & $\begin{array}{l}0.4 \% \mathrm{Pt} / \mathrm{Ce}-\mathrm{ZrO}_{2} \\
\text { impregnation }\end{array}$ & $\begin{array}{l}\text { TPO, } 700 \mathrm{mg} \text {, Soot/cat } \\
1: 20 \text {, loose contact }\end{array}$ & $\begin{array}{l}\text { Heated } 5^{0} \mathrm{C} / \mathrm{min} \text { in air } \\
\text { flow } 300 \mathrm{ml} / \mathrm{min} .\end{array}$ & Isothermal & 161 \\
\hline 8. & $\begin{array}{l}1 \% \mathrm{Pt} / \mathrm{Al}_{2} \mathrm{O}_{3} \\
\text { Impregna-tion }\end{array}$ & $\begin{array}{l}\text { TPO, } 500 \mathrm{mg} \text {, Soot } / \text { cat } \\
=1 / 9, \text { loose contact }\end{array}$ & $\begin{array}{l}\text { Heated } 2^{\circ} \mathrm{C} / \mathrm{min} \text { in air } \\
\text { flow } 50 \mathrm{ml} / \mathrm{min} \text {. }\end{array}$ & $\begin{array}{l}\text { Non } \\
\text { Isothermal }\end{array}$ & 161 \\
\hline 8 & $\begin{array}{l}1 \% \mathrm{Pt} / \mathrm{CeO}_{2} \\
\text { Impregna-tion }\end{array}$ & $\begin{array}{l}\text { TPO, } 500 \mathrm{mg} \text {, Soot } / \mathrm{cat} \\
=1 / 9, \text { loose contact }\end{array}$ & $\begin{array}{l}\text { Heated } 2^{\circ} \mathrm{C} / \mathrm{min} \text { in air } \\
\text { flow } 50 \mathrm{ml} / \mathrm{min} \text {. }\end{array}$ & $\begin{array}{l}\text { Non } \\
\text { Isothermal }\end{array}$ & 154 \\
\hline 8 & $\begin{array}{l}1 \% \mathrm{Pt} / \mathrm{La}_{2} \mathrm{O}_{3} \\
\text { impregnation }\end{array}$ & $\begin{array}{l}\text { TPO, } 500 \mathrm{mg} \text {, Soot } / \text { cat } \\
=1 / 9, \text { loose contact }\end{array}$ & $\begin{array}{l}\text { Heated } 2^{\circ} \mathrm{C} / \mathrm{min} \text { in air } \\
\text { flow } 50 \mathrm{ml} / \mathrm{min} \text {. }\end{array}$ & $\begin{array}{l}\text { Non } \\
\text { Isothermal }\end{array}$ & 147 \\
\hline 8 & $\begin{array}{l}1 \% \mathrm{Pt} / \mathrm{SiO}_{2} \\
\text { Impregna-tion }\end{array}$ & $\begin{array}{l}\text { TPO, } 500 \mathrm{mg} \text {, Soot } / \text { cat } \\
=1 / 9, \text { loose contact }\end{array}$ & $\begin{array}{l}\text { Heated } 2^{\circ} \mathrm{C} / \mathrm{min} \text { in air } \\
\text { flow } 50 \mathrm{ml} / \mathrm{min} \text {. }\end{array}$ & $\begin{array}{l}\text { Non } \\
\text { Isothermal }\end{array}$ & 159 \\
\hline 8 & $\begin{array}{l}1 \% \mathrm{Pt} / \mathrm{TiO}_{2} \\
\text { Impregna-tion }\end{array}$ & $\begin{array}{l}\text { TPO, } 500 \mathrm{mg} \text {, Soot } / \mathrm{cat} \\
=1 / 9, \text { loose contact }\end{array}$ & $\begin{array}{l}\text { Heated } 2^{\circ} \mathrm{C} / \mathrm{min} \text { in air } \\
\text { flow } 50 \mathrm{ml} / \mathrm{min} \text {. }\end{array}$ & $\begin{array}{l}\text { Non } \\
\text { Isothermal }\end{array}$ & 158 \\
\hline 8 & $\begin{array}{l}1 \% \mathrm{Pt} / \mathrm{ZrO}_{2} \\
\text { Impregn-ation }\end{array}$ & $\begin{array}{l}\text { TPO, } 500 \mathrm{mg} \text {, Soot } / \text { cat } \\
=1 / 9, \text { loose contact }\end{array}$ & $\begin{array}{l}\text { Heated } 2^{\circ} \mathrm{C} / \mathrm{min} \text { in air } \\
\text { flow } 50 \mathrm{ml} / \mathrm{min} \text {. }\end{array}$ & $\begin{array}{l}\text { Non } \\
\text { Isothermal }\end{array}$ & 158 \\
\hline 8 & $\mathrm{Al}_{2} \mathrm{O}_{3}$ & $\begin{array}{l}\text { TGA, 500mg, Soot } / \text { cat }= \\
9 / 7 \text {, loose contact }\end{array}$ & $\begin{array}{l}\text { Heated } 5^{\circ} \mathrm{C} / \mathrm{min} \text { in air } \\
\text { flow } 100 \mathrm{ml} / \mathrm{min} \text {. }\end{array}$ & $\begin{array}{l}\text { Non } \\
\text { Isothermal }\end{array}$ & 165 \\
\hline 8 & $\mathrm{CeO}_{2}$ & $\begin{array}{l}\text { TGA,500mg, Soot/cat }= \\
7 / 5 \text {, loose contact }\end{array}$ & $\begin{array}{l}\text { Heated } 5^{\circ} \mathrm{C} / \mathrm{min} \text { in air } \\
\text { flow } 100 \mathrm{ml} / \mathrm{min} \text {. }\end{array}$ & $\begin{array}{l}\text { Non } \\
\text { Isothermal }\end{array}$ & 159 \\
\hline 8 & $\mathrm{La}_{2} \mathrm{O}_{3}$ & $\begin{array}{l}\text { TGA,500 mg } \\
\text { loose contact }\end{array}$ & $\begin{array}{l}\text { Heated } 5^{\circ} \mathrm{C} / \mathrm{min} \text { in air } \\
\text { flow } 100 \mathrm{ml} / \mathrm{min} \text {. }\end{array}$ & $\begin{array}{l}\text { Non } \\
\text { Isothermal }\end{array}$ & 159 \\
\hline 8 & $\mathrm{SiO}_{2}$ & $\begin{array}{l}\text { TGA, } 500 \mathrm{mg} \text {, Soot } / \text { cat }= \\
7 / 11, \text { loose contact }\end{array}$ & $\begin{array}{l}\text { Heated at } 5^{\circ} \mathrm{C} / \mathrm{min} \text { in air } \\
\text { flow } 100 \mathrm{ml} / \mathrm{min} \text {. }\end{array}$ & $\begin{array}{l}\text { Non } \\
\text { Isothermal }\end{array}$ & 156 \\
\hline 8 & $\mathrm{TiO}_{2}$ & $\begin{array}{l}\text { TGA, } 500 \mathrm{mg}, \text { Soot } / \text { cat }= \\
8 / 6 \text {, loose contact }\end{array}$ & $\begin{array}{l}\text { Heated at } 5^{\circ} \mathrm{C} / \mathrm{min} \text { in air } \\
\text { flow } 100 \mathrm{ml} / \mathrm{min} \text {. }\end{array}$ & $\begin{array}{l}\text { Non } \\
\text { Isothermal }\end{array}$ & 164 \\
\hline 8 & $\mathrm{ZrO}_{2}$ & $\begin{array}{l}\text { TGA, } 500 \mathrm{mg}, \text { Soot } / \text { cat }= \\
1 / 7, \text { loose contact }\end{array}$ & $\begin{array}{l}\text { Heated at } 5^{0} \mathrm{C} / \mathrm{min} \text { in air } \\
\text { flow } 100 \mathrm{ml} / \mathrm{min} \text {. }\end{array}$ & $\begin{array}{l}\text { Non } \\
\text { Isothermal }\end{array}$ & 158 \\
\hline
\end{tabular}

For experimental studies the soot-catalyst mixture, in an appropriate ratio, are milled in an agate mortar for "tight contact" or mixed carefully with a spatula for "loose contact" [7].

In most of the studies reported in the literature, the catalyst performances are based on the light-off temperatures. The comparison of the catalyst performances may be consistent within one set of data, but the differences in the experimental conditions such as the heating rates and the gas flow rates may cause differences in the light-off temperatures. A better tool for catalyst performance comparison is to report the activation energy for the process [8]. Furthermore, the activation energy data are needed for the modelling and design of the catalytic soot converters. Despite the significant progress in soot oxidation studies and the extended literature, there is still high uncertainty concerning the corresponding kinetic equations. Great scatter is observed regarding the reported activation energy (E), the order of reaction with respect to both the oxidants and the running soot mass [8-10] in the oxidation reaction. The reported activation energy (E) of the various soot-catalyst mixtures is given in Table 1.

The basic reasons, which lead to those discrepancies, are related with the sample and experimental setup characteristics. The commonly used synthetic soot samples are not necessarily equivalent to real diesel soot. Then again the quality of real soot is not constant and depends on engine and operational parameters. And finally, the experimental setup itself may impose uncertainties, such as rate controlling mass transfer limitations, etc.

Different experimental approaches have been used in the literature including thermogravimetric analysis (TG) [11-15], flow and bed reactors, semi-batch reactor [10], etc. [16, 17]. Several studies [18-22] on the kinetics of noncatalytic and catalytic soot oxidation have been reported in the literature. It is concluded [23] that more detailed insight in the kinetics and mechanism of soot oxidation might help in developing more active and selective soot oxidation 
catalysts and in modelling of catalytic converters $[10,21,24]$.

A platinum group metals (PGM) coated DPF has been presented as an efficient after-treatment system $[25,26]$. But in recent years, considering the high cost, limited availability of the noble metals and their instability with impurities, more attention has been focused on the base metal catalysts $[27,28]$. In this context PGM-free, $\mathrm{CuO}$ $\mathrm{CeO}_{2}$ based catalysts are expected to be a good alternative for diesel soot oxidation [29].

Thus, this study deals with the kinetics of catalyzed oxidation of diesel soot in a laboratory set-up, using a very sturdy and selective, $\mathrm{Cu}-\mathrm{Ag}$ Cr-K-Ce-Zr-Al catalyst [30] prepared by citric acid sol gel method. The soot oxidation was investigated under isothermal conditions at ambient pressure in a specially designed mini semi-batch reactor.

\section{Materials and methods}

\subsection{Catalyst preparation}

$\mathrm{Cu}-\mathrm{Ag}$-Cr-K-Ce-Zr-Al mixed oxides, with $\mathrm{Ce} / \mathrm{Zr}$ and $\mathrm{Cu}+\mathrm{Ag} /(\mathrm{Cu}+\mathrm{Cr}+\mathrm{Ag}+\mathrm{K}+\mathrm{Ce}+\mathrm{Zr}+\mathrm{Al})$ molar ratio equal to $5 / 4$ and $1 / 10$ respectively were prepared by citric acid sol-gel methods. The nitrates $\mathrm{Cu}$ $\left(\mathrm{NO}_{3}\right)_{2} .3 \mathrm{H}_{2} \mathrm{O}, \quad\left(\mathrm{NH}_{4}\right)_{2} \mathrm{Cr}_{2} \mathrm{O}_{7}, \quad \mathrm{AgNO}_{3}, \mathrm{KNO}_{3}$, $\mathrm{Ce}\left(\mathrm{NO}_{3}\right)_{3} \cdot 6 \mathrm{H}_{2} \mathrm{O}, \quad \mathrm{ZrO}\left(\mathrm{NO}_{3}\right)_{2} \cdot \mathrm{H}_{2} \mathrm{O}, \quad \mathrm{Al}\left(\mathrm{NO}_{3}\right)_{3} \cdot 9 \mathrm{H}_{2} \mathrm{O}$ were mixed in deionised water according to the desired molar ratio. Citric acid was added as the complexing agent with a 1.3:1 ratio. Appropriate poly-glycol (poly ethylene glycol) is added to the weight of $10 \%$ citric acid. The blended solution is sufficiently mixed in a magnetic stirrer and heated at $80^{\circ} \mathrm{C}$ till transparent gel was formed. The resulting gel was dried at $110^{\circ} \mathrm{C}$ in an oven overnight. The received powder was submitted to decompose at $300{ }^{\circ} \mathrm{C}$ for $1 \mathrm{~h}$ and calcination at 500 ${ }^{\circ} \mathrm{C}$ for $3 \mathrm{~h}$ under static air in a muffle furnace. The

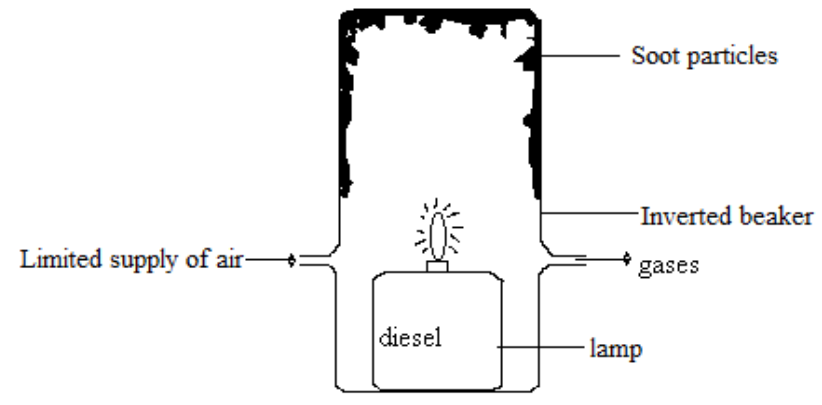

Figure 1. Schematic diagram showing soot preparation powder was cooled to room temperature in the furnace to obtain the so-called fresh samples.

\subsection{Soot preparation}

The soot was prepared by partial combustion of commercial diesel obtained from Hindustan petroleum (HP) in a lamp with a limited supply of air [31-33] as shown in Figure 1. The deposited soot on the inner walls of an inverted beaker was collected and then dried in an oven for overnight at $120{ }^{\circ} \mathrm{C}$.

\subsection{Bench Scale Reactor}

Experimental set-up for collecting kinetic data on isothermal air oxidation of soot is shown in Figure 2. It is consisted of a tubular furnace with a microprocessor based temperature controller, a quartz reactor and a condenser for condensing water vapour and cooling the product gas to room temperature. The reactor has a sample tube (as shown in Figure 2) attached to it by B-14 socket joint and a thermocouple well for measuring the temperature of the soot-catalyst bed. The bends of the sample tube and the tube connecting the sample tube to the reactor are such that when the sample tube is at position $\mathrm{Y}$, the solid sample falls into the reactor.

The outlet of the reactor is connected to a cooler cum condenser as shown in the figure. The furnace temperature can be controlled to $\pm 0.5^{\circ} \mathrm{C}$ and the temperature of the bed is measured by a separate temperature indicator (T). There is a hole in the lower part of the outer tube of the reactor, to take care of breakage due to the expansion or

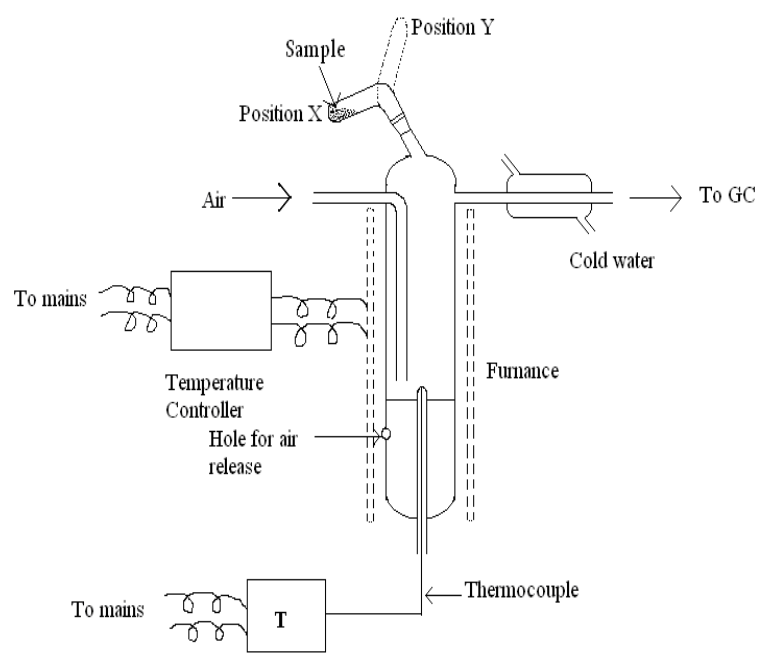

Figure 2. Schematic diagram of the mini semibatch reactor 
contraction of air in between co-axial tubes as the unit is subjected to the variation of temperature from ambient to the reaction temperature. The reactor was mounted vertically.

\subsection{Experimental procedure}

A known weight of the soot-catalyst mixture was taken in the sample tube and it was connected to the system (position X). Before the oxidation reaction, the soot-catalyst mixture, in a $1 / 10$ weight ratio, were milled in an agate mortar for "tight contact". $110 \mathrm{mg}$ of this catalyst-soot mixture was placed in the sample tube. The heating of the furnace was started and the dry and $\mathrm{CO}_{2}$ free air was fed at flow rate of $150 \mathrm{ml} /$ min. When the reactor attained the required temperature shown by the temperature indicator (T) the sample was dropped in the reactor by turning the sample tube by $180^{\circ}$ (i.e. position Y) and the composition of the reactor outlet gases were analysed by a gas chromatograph as a function of time. Gaseous products were analysed for $\mathrm{CO}$ and $\mathrm{CO}_{2}$ with the help of an online gas chromatograph using Porapack-Q column, methaniser and FID detector. GC analysis of the product stream showed only peak for $\mathrm{CO}_{2}$, no peak was observed corresponding to $\mathrm{CO}$ retention time. This shows very high selectivity of the catalyst for $\mathrm{CO}_{2}$. The isothermal catalytic soot oxidation data were collected in the temperature range of $340-420^{\circ} \mathrm{C}$.

\section{Results and Discussion}

\subsection{Catalyzed soot oxidation}

The kinetics of catalyzed air oxidation of diesel soot in laboratory conditions, using a very sturdy and selective, $\mathrm{Cu}-\mathrm{Ag}-\mathrm{Cr}-\mathrm{K}-\mathrm{Ce}-\mathrm{Zr}-\mathrm{Al}$ catalyst were studied under isothermal conditions in a semi batch reactor. The catalyst selectivity was $100 \%$ for $\mathrm{CO}_{2}$, as no $\mathrm{CO}$ was detected in the product stream. The experimental data, $\% \mathrm{CO}_{2} \mathrm{Vs}$ time plot at five different temperatures (340- 420 $\left.{ }^{\circ} \mathrm{C}\right)$ are presented in Figure 3. The fraction conversion of soot, (a) is defined as:

$$
\mathrm{a}=1-\mathrm{m} / \mathrm{m}_{0}
$$

where, $\mathrm{m}$ and $\mathrm{m}_{0}$ are the running and the initial sample mass respectively. The value of $a$ at various extent of reaction is calculated using the following formula:

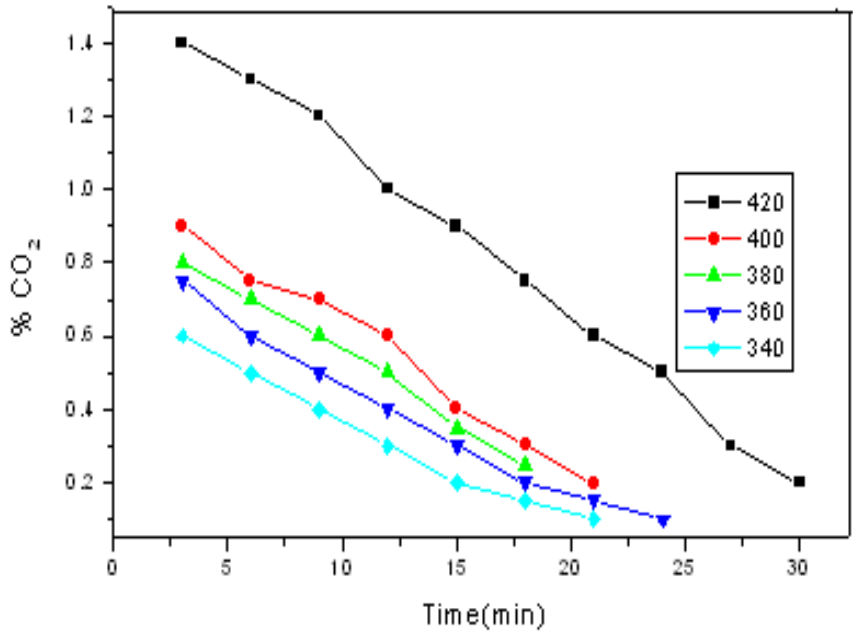

Figure 3. Composition of $\mathrm{CO}_{2}$ in the effluent stream during soot oxidation

$$
\alpha=\sum_{0}^{\mathrm{t}}\left(\% \mathrm{CO}_{2}\right) \Delta \mathrm{t} / \underset{0}{\Sigma}\left(\% \mathrm{CO}_{2}\right) \Delta \mathrm{t}
$$

Where, $\Delta \mathrm{t}$ is the time differences. The empirical rate law equations as favoured by Levenspiel [34] have been used to derive the kinetic parameters of diesel soot oxidation. The assumption often made in literature $[15,16]$ is that the global soot oxidation rate can be described by a first order kinetic equation with respect to sample mass:

$$
\begin{aligned}
\text { Rate } & =-\mathrm{dm} / \mathrm{dt}=\mathrm{k} \cdot \mathrm{m} \cdot\left[\mathrm{O}_{2}\right]^{\mathrm{n}} \\
\text { or } \quad \text { Rate } & =\mathrm{d} \alpha / \mathrm{dt}=\mathrm{k}(1-\alpha)\left[\mathrm{O}_{2}\right]^{\mathrm{n}}
\end{aligned}
$$

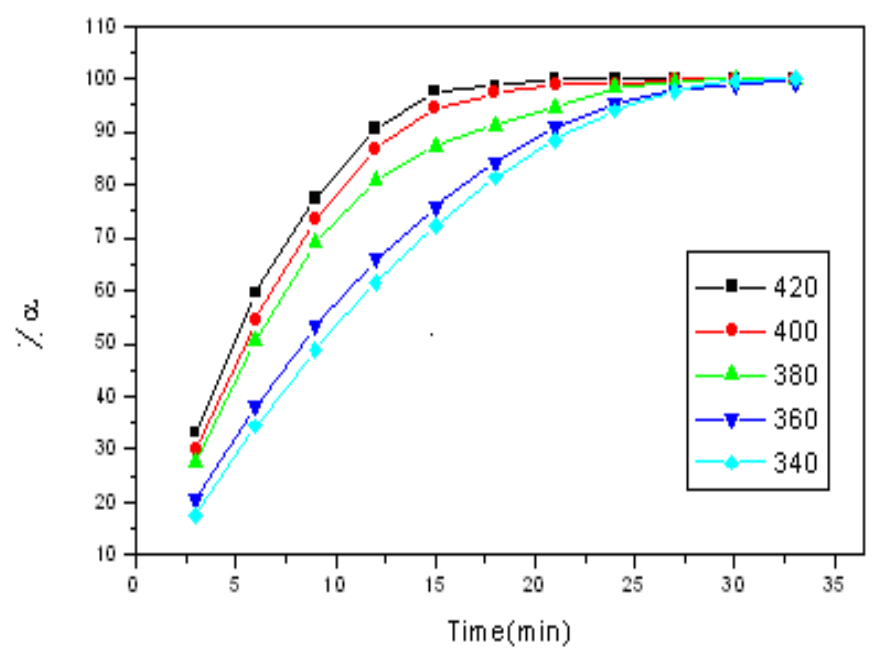

Figure 4. Percent soot conversion (\% a) versus time 


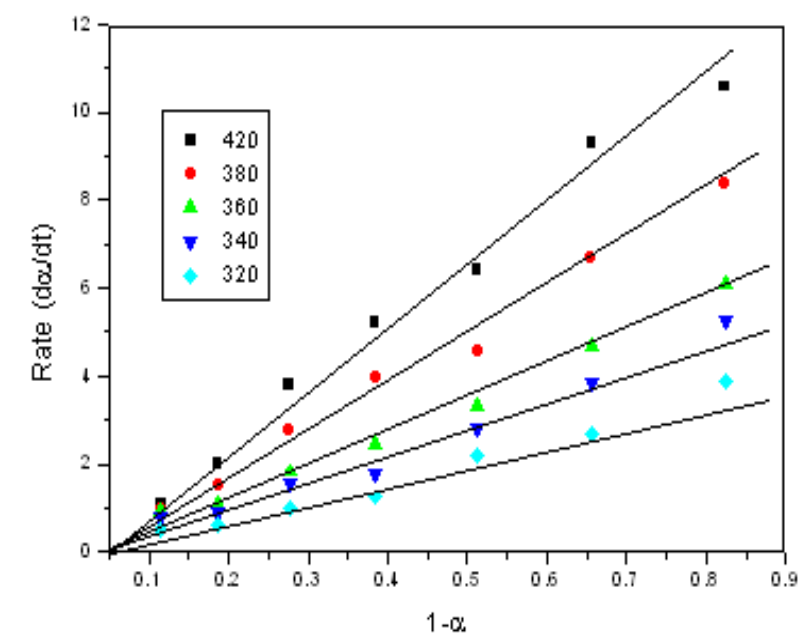

Figure 5. Rate of soot oxidation (da/dt) as a function of (1-a)

Where, $\mathrm{k}$ is the reaction rate constant and $\mathrm{n}$ is the order of reaction with respect to oxygen. In the present study flowing oxygen was in large excess, therefore the rate expression reduces to overall pseudo first order:

$$
\text { Rate }=\mathrm{d} \alpha / \mathrm{dt}=\mathrm{k}(1-\alpha)
$$

The rate of oxidation reaction at any instance was obtained by taking slope of soot conversion (a) versus time plot (Figure 4 ).

Linear plots passing through origin were obtained when rate of soot oxidation (da/dt) as a function of (1-a) were plotted (Figure 5). Slopes of the lines gave reaction rate constant $(\mathrm{k})$ at various temperatures. The values of reaction rate constants at various temperatures are reported in Table 2. The temperature dependence of the reaction rate is usually described by the Arrhenius equation:

Table 2. Reaction rate constant as a function of temperature

\begin{tabular}{llll}
\hline $\begin{array}{c}\text { Temp. } \\
(\mathrm{K})\end{array}$ & $\begin{array}{l}1 / \mathrm{T} \times 10^{3} \\
\left(\mathrm{~K}^{-1}\right)\end{array}$ & $\begin{array}{l}\mathrm{k} \\
\left(\mathrm{min}^{-1}\right)\end{array}$ & $\ln (\mathrm{k})$ \\
\hline 613 & 1.631 & 4.4 & 1.481 \\
633 & 1.579 & 6.6 & 1.887 \\
648 & 1.543 & 7.5 & 2.014 \\
673 & 1.485 & 12.0 & 2.484 \\
693 & 1.440 & 18.4 & 2.912 \\
\hline
\end{tabular}

$$
\begin{gathered}
\mathrm{k}=\mathrm{k}_{0} \exp \left(-\mathrm{E}_{\mathrm{a}} / \mathrm{RT}\right) \\
\text { or } \ln (\mathrm{k})=\ln \left(\mathrm{k}_{0}\right)-\left(\mathrm{E}_{\mathrm{a}} / \mathrm{RT}\right)
\end{gathered}
$$

where, $\mathrm{T}$ is the absolute temperature, $\mathrm{k}_{0}$ is the preexponential factor, $\mathrm{R}$ is the universal gas constant and $\mathrm{Ea}$ is the activation energy. Figure 6 shows a linear relationship between $\ln \mathrm{k}$ and $1 / \mathrm{T}$. Thus the reaction rate constants follow Arrhenius law.

The activation energy $\left(E_{a}\right)$ and frequency factor $\left(\mathrm{k}_{0}\right)$ were calculated measuring the slope and intercept respectively of the plot $\ln (\mathrm{k})$ vs. $1 / \mathrm{T}$ (Figure 6). The values of $\mathrm{E}_{\mathrm{a}}$ and $\mathrm{k}_{0}$ are found to be $160 \mathrm{~kJ} / \mathrm{mol}$ and $3.52 \times 10^{12} \mathrm{sec}^{-1}$ respectively under the conditions investigated in the present studies. On the basis of the experimental findings the rate of soot oxidation over $\mathrm{Cu}-\mathrm{Cr}-\mathrm{Ag}-\mathrm{K}-\mathrm{Ce}-\mathrm{Zr}-\mathrm{Al}$ catalyst in the temperature range of $613-693 \mathrm{~K}$ can be expressed as follows:

$$
\text { Rate }=3.52 \times 10^{12} \exp (-160000 / \mathrm{RT})(1-\alpha)
$$

This empirical rate expression can be adequately used in modeling of the diesel soot filter using the mentioned catalyst in the present studies.

\section{Conclusion}

Soot oxidation was studied in a specially designed mini semi-batch reactor. The study of soot oxidation kinetics in the mini-scale reactor revealed that it assures practically isothermal conditions in the sample (the difference between the inlet and outlet temperature was not observed). High flow rate of air indicate that there was no mass transfer limitations and that the chemical kinetics control the reaction under the investigated conditions. Intrinsic reaction rate of air oxidation of diesel soot over $\mathrm{Cu}-\mathrm{Cr}-\mathrm{Ag}-\mathrm{K}-\mathrm{Ce}-\mathrm{Zr}$-Al catalyst was determined as a function of temperature and fractional conversion. Under the high air flow rate assuming pseudo first order reaction the activation energy of soot oxidation was found to be, $\mathrm{E}_{\mathrm{a}}=160$ $\mathrm{kJ} / \mathrm{mol}$. 


\section{References}

[1] Kalogirou, M.; Pistikopoulos, P.; Ntziachristos, L.; and Samaras, Z. 2009. Isothermal soot oxidation experiments with intermediate gas change in a perkinelmer TGA6. J. Therm. Anal. Cal. 95: 141-147.

[2] Lloyd, A.C.; and T.A. Cackette. 2001. Diesel Engines: Environmental Impact and Control. J. Air \& Waste Manage. Assoc. 51: 809-847.

[3] Walker, A.P. 2004. Controlling particulate emissions from diesel vehicles: A Review. Topics in Catal 28: 165-170.

[4] Stamatelos, A.M. 1997. A review of the effect of particulate traps on the efficiency of vehicle diesel engines.Energy Convers. Mgmt. 38: 83-99.

[5] Fino, D. 2007. Diesel emission control: A review of catalytic filters for particulate removal. Sci. \& Technol. of Adv. Materials 8: 93-100.

[6] Lopez-Fonseca, R.; Elizundia, U.; Landa, I.; GutiérrezOrtiz, M.A.; Gonza'lez-Velasco, J.R. 2005. Kinetic analysis of non-catalytic and Mn-catalysed combustion of diesel soot surrogates. Appl Catal B 61: 150-158.

[7] Van Setten, B.A.A.L.; Schouten, J.M.; Makkee, M.; Moulijn, J.A. 2000. Realistic contact for soot with an oxidation catalyst for laboratory studies. Appl. Catal. B 28: 253-257.

[8] Pierre Darcy, Patrick Da Costa, Henry Mellotte,JeanMichel Trichard, Gerald Djega-Mariadassou. 2007. Kinetics of catalyzed and non-catalyzed oxidation of soot from a diesel engine. Catalysis Today 119: 252256.

[9] Stanmore, B.R.; Brilhac, J.F.; Gilot, P. 2001. The oxidation of soot: a review of experiments, mechanisms and models. Carbon 39: 2247-68.

[10] Dernaika, B.; Uner, D. 2003. A simplified approach to determine the activation energies of uncatalyzed and catalyzed combustion of soot. Appl. Catal. B 40: 219229

[11] Illekova, E.; and Csomorova, K.2005. Kinetics of oxidation in various forms of carbon. J. Therm. Anal. Cal. 80: 103-108.

[12] Lopez-Fonseca, R.; Landa, I.; Gutierrez-Ortiz, M. A.; and Gonzalez-Velasco, J. R. 2005. Non- isothermal analysis of the kinetics of the combustion of carbonaceous materials, J. Therm. Anal. Cal.80: 65-69.

[13] Mianowski, A.; Bigda, R. ; and Zymla, V. 2006. Study on kinetics of combustion of brick-shaped carbonaceous materials. J. Therm. Anal.Cal. 84: 563-574.

[14] Neeft, J.; Hoornaert, F. ; Makkee, M.; and Moulijn, J. A.1996. The effects of heat and mass transfer in thermogravimetrical analysis. A case study towards the catalytic oxidation of soot. Thermochim. Acta, 287: 261-278.

[15] Stratakis, G. A.; and Stamatelos, A. M. 2003. Thermogravimetric analysis of soot emitted by a modern diesel engine run on catalyst-doped fuel. Combust. Flame. 132: 157-169.

[16] Yezerets, A.; Currier, N. W.; and Eadler, H. A. 2003. Experimental Determination of the Kinetics of Diesel Soot Oxidation By $\mathrm{OD}_{2}$ - Modelling Consequences. SAE technical paper, 2003-01-0833.

[17] Messerer, A.; Niessner, R.; and Poschl, U. 2006.
Comprehensive kinetic characte- rization of the oxidation and gasification of model and real diesel soot by nitrogen oxides and oxygen under engine exhaust conditions: Measurement, Langmuir-Hinshelwood, and Arrhenius parameters. Carbon 44: 307-324.

[18] Ahlstrom, A. F. and Odenbrand, C. U. I. Combustion characteristics of soot deposits from diesel engines.Carbon 1989, 27, 475-483.

[19] Du, Z., Sarofim, A. F., Longwell, J. P. and Tognotti, L. 1991. In Fundamental Issues in Control of Carbon Gasification Reactivity, ed. J. Lahaye and P. Ehrburger. Kluwer, Dordrecht . 91.

[20] Du, Z.; Sarofim, A. F.; Longwell, J. P.; and Mims, C. A.1991. Kinetic measurement and modeling of carbon oxidation. Energy and Fuels, 5: 214-221.

[21] Gilot, P.; Bonnefoy, F.; Marcuccilli, F.; and Prado, G.1993. Determination of kinetic data for soot oxidation. Modeling of competition between oxygen diffusion and reaction during thermogravimetric analysis. Combust. Flame 95: 87-100.

[22] Otto, K.; Sieg, M. H.; Zinbo, M.; and Bartosiewicz, L.1980. The Oxidation of Soot Deposits From Diesel Engines. SAE Paper 800336.

[23] Neeft, J.P.A. 1995.Catalytic oxidation of soot. Potential for the reduction of diesel particulate emissions, Ph.D. thesis, Delft University of Technology, Delft.

[24] Kalogirou, M.; Samaras Z. 2010. Soot oxidation kinetics from TG experiments. J Therm Anal Calorim 99: 10051010.

[25] Castoldi, L.; Matarrese, R.; Lietti, L.; and Forzatti, P. 2006. Simultaneous removal of NOx and soot on Pt$\mathrm{Ba} / \mathrm{Al}_{2} \mathrm{O}_{3}$ NSR catalysts. Appl. Catal. B 64: 25-34.

[26] Matarrese, R.; Castoldi, L.; Lietti, L.; and Forzatti, P. 2007. High performances of Pt- $\mathrm{K} / \mathrm{Al}_{2} \mathrm{O}_{3}$ versus Pt$\mathrm{Ba} / \mathrm{Al}_{2} \mathrm{O}_{3}$ LNT catalysts in the simultaneous removal of $\mathrm{NO}_{\mathrm{x}}$ and soot. Top. Catal. 42-43: 293-297.

[27] Lopez-Sua rez, F. E.; Bueno-Lopez, A.; and Illan-Gomez M. J. 2008. $\mathrm{Cu} / \mathrm{Al}_{2} \mathrm{O}_{3}$ catalysts for soot oxidation: Copper loading effect. Appl.Catal. B 84: 651-658.

[28] Fua, M.; Yuea, X.; Yea, D.; Ouyanga, J.; Huanga, B.; Wua, J.; and Liangc, H. 2010. Soot oxidation via $\mathrm{CuO}$ doped $\mathrm{CeO}_{2}$ catalysts prepared using coprecipitation and citrate acid complex-combustion synthesis. Catal. Today available online.

[29] Reddy, B. M.; and Rao, K. N. 2009. Copper promoted ceria-zirconia based bimetallic catalysts for low temperature soot oxidation. Catalysis Commun 10: 1350-1353.

[30] Prasad R., Bella V.R. Comparison of Preparation Methods of copper based PGM-free diesel-soot oxidation catalysts. To be published.

[31] Serra, V.; Saracco, G.; Badini, C.; Specchia, V. 1997. Combustion of carbonaceous materials by $\mathrm{Cu}-\mathrm{K}-\mathrm{V}$ based catalysts: II. Reaction mechanism. Appl. Catal. B 11: 329-346.

[32] Querini, C.; Ulla, M.; Requejo, F.; Soria, J.; Sedran, U.; Miro, E. 1998. Catalytic combustion of diesel soot particles. Activity and characterization of $\mathrm{Co} / \mathrm{MgO}$ and $\mathrm{Co}, \mathrm{K} / \mathrm{MgO}$ catalysts. Appl. Catal. B 15: 5-19.

[33] Shangguan, W. F.; Teraoke, Y.; Kagawa, S. 1997. Kinetics of soot- $\mathrm{O}_{2}$, soot-NO and soot- $\mathrm{O}_{2}$ - $\mathrm{NO}$ reactions over spinel-type $\mathrm{CuFe}_{2} \mathrm{O}_{4}$ catalyst. Appl. Catal. B 12: 
237-247.

[34] Levenspiel, O. 1999. Chemical Reaction Engineering,

John Wiley Eastern \& Sons, New York, 380. 